\title{
Microcephaly in Colombia before the Zika outbreak: A systematic literature review
}

\author{
Estephanía Candelo1,2, Gabriela Caicedo', Max M. Feinstein ${ }^{3}$, Harry Pachajoa ${ }^{1,4}$ \\ 1 Centro de Investigaciones en Anomalías Congénitas y Enfermedades Raras, Universidad ICESI, Cali, Colombia \\ 2 Biomaterials and Tissues Engineering, University College London, London, United Kingdom \\ 3 School of Medicine, Case Western Reserve University, Cleveland, United States \\ 4 Departamento de Pediatría, Fundación Valle del Lili, Cali, Colombia
}

Introduction: Microcephaly is characterized by a smaller than normal head circumference. Recently, Zika virus (ZV) has been associated with microcephaly.

Objective: To describe the prevalence of microcephaly in Colombia taking as the baseline the information from the period before the Zika virus infection epidemics.

Materials and methods: We reviewed Medline, Scopus, Scielo, Lilacs and annual reports of congenital malformation monitoring systems across Latin America, among others sources, for articles published before April, 2015, reporting the prevalence of microcephaly in Colombia between 1982 and 2013.

Results: We identified 32 non-duplicate articles; we selected 25 articles for revision of which 12 met the criteria for inclusion in the systematic review, including 2,808,308 births.

Conclusions: The prevalence of microcephaly in Colombia from 1982 to 2013, before the introduction of ZV, ranged from 0.3 to 3.1 per 10,000 births, with an average of $1.8(95 \% \mathrm{Cl} 1.7-1.8)$ per 10,000 births. These findings are important to determine if the prevalence after the introduction of the Zika virus infection registered significant changes.

Key words: Microcephaly; Zika virus infection; congenital abnormalities; prevalence; Colombia. doi: https://doi.org/10.7705/biomedica.v38i0.4413

\section{Microcefalia en Colombia antes de la epidemia del Zika: revisión sistemática de la literatura}

Introducción. La microcefalia consiste en una circunferencia cefálica menor de la esperada. Recientemente, el virus del Zika se ha asociado con esta condición.

Objetivo. Describir la prevalencia de la microcefalia en Colombia, estableciendo como línea de base el periodo anterior a la epidemia del virus del Zika.

Materiales y métodos. Se revisaron las bases de datos Medline, Scopus, Scielo, Lilacs y el reporte anual de malformaciones congénitas en Latinoamérica, así como otras fuentes publicadas antes de abril de 2015 con los datos de prevalencia de la microcefalia en Colombia entre 1982 y 2013.

Resultados. Se detectaron 32 artículos no duplicados, se revisaron 25 y se seleccionaron 12 que cumplían con los criterios de inclusión para la revisión sistemática, los cuales registraban 2'808.308 nacimientos.

Conclusiones. La prevalencia de la microcefalia en Colombia entre 1982 y 2013, antes de la epidemia del virus del Zika, oscilaba entre 0,3 y 3,1 por 10.000 nacimientos, con un promedio de $1,8\left(\right.$ IC $_{95 \%}$ 1,7$1,8)$. Este dato es importante para determinar la diferencia en la prevalencia después de la introducción del virus del Zika en Colombia.

Palabras clave: microcefalia; infección por el virus del Zika; anomalías congénitas; prevalencia; Colombia. doi: https://doi.org/10.7705/biomedica.v38i0.4413

Corresponding author:

Harry Pachajoa, MD, Centro de Investigaciones en Anomalías Congénitas y Enfermedades Raras, Universidad ICESI, Calle $18 \mathrm{~N}^{\circ} 122-135$, Cali, Colombia

Telephone: (572) 555 2334; fax: (216) 3680564

hmpachajoa@icesi.edu.co

Received: 03/12/18; accepted: 06/15/18
The most common defects found in newborns in South America are cardiac alterations (28 per 10,000 live births), defects of the neural tube closure (24 per 10,000 live births), Down syndrome (16 per 10,000 live births), cleft lip and cleft palate (15 per 10,000 live births), and defects of the

\section{Author's contributions:}

Estephanía Candelo and Harry Pachajoa: conception and design of the study

All authors contributed to the data analysis and interpretation and to the writing of the manuscript. 
abdominal wall (4 per 10,000 live births) (1). Some congenital defects, such as microcephaly, are reported less frequently due to their low prevalence. Given the introduction of Zika virus (ZV), however, microcephaly has gained clinical relevance.

Microcephaly is an important neurological manifestation that may result from insults to early brain development. It is part of the hundreds of genetic syndromes (2) and it has been variably defined in the literature. The World Health Organization (WHO) defines microcephaly as a head circumference less than two standards below the median for age and sex, and severe microcephaly as a head circumference less than three standard deviations below the median for age and sex (3). One study reported that approximately $61 \%$ of children with a head circumference less than two standard deviations have no abnormal findings on evaluation with imaging techniques (4). When imaging techniques reveal brain malformations, the following findings have been documented: Ventricular dilatation, mild atrophy (31\%), moderate to severe atrophy with ventricular dilation $(28 \%)$, and isolated parenchymal abnormalities (2\%) (4). Other studies using magnetic resonance imaging (MRI) have reported the presence of brain abnormalities in $67-80 \%$ patients with microcephaly $(5,6)$. MRI is the most sensitive diagnostic tool for the evaluation of microcephaly.

Microcephaly may be congenital or postnatal (7), which means a failure in brain growth after birth. It is also described as syndromic or primary (known as vera microcephaly). This classification depends on the presence or absence of extra-cranial malformations or facial dimorphism (2). Microcephaly is sometimes the first sign of a congenital condition, a genetic anomaly or an acquired problem (due to congenital infection) (8). Genetic causes have been reported in approximately $15.5 \%$ to $53.3 \%$ of cases. The prevalence of metabolic disorders is unknown, but it is estimated to be $1 \%$ to $5 \%$. The conditions associated with microcephaly include epilepsy $(40 \%)$, cerebral palsy $(20 \%)$, intellectual disability (50\%) and eye problems (20-50\%) (2). A diagnosis of microcephaly has serious clinical implications, as there is a direct correlation between the degree of microcephaly and the degree of intellectual disability (9).

Since the end of 2015, microcephaly has received global attention due to the ZV epidemic in the Americas. Different criteria for causality have been established, including a spatial-temporal relationship and biological plausibility that entails identification of $\mathrm{ZV}$ in the brain tissue of affected fetuses (10). Animal models have been developed to try to provide a pathophysiological explanation for microcephaly via congenital infection with the virus (11). In February 2016, the first case of intrauterine transmission of ZV was reported, which featured neurological malformations in the fetus (12). In the months following the emergence of $Z V$ in Brazil, an annual increase of up to 20 times the number of cases of birth defects has been reported, with a marked increase in microcephaly in particular (13). In 2015, 1,248 new suspected cases of microcephaly were reported in Brazil, with a prevalence of 99.7 per 100,000 live births. With these observations, the Brazilian Ministry of Health confirmed the relationship between ZV and microcephaly (14). Subsequently, WHO declared an epidemiological alert regarding ZV and its association with congenital malformations and neurological syndromes (15). Thus, ZV and its association with birth defects have recently become a public health problem of international importance (16).

So far, associative epidemiological links exist between ZV and microcephaly. This has resulted from the increase in the number of newborn infants with microcephaly $(13,17)$ in countries where there is a high rate of suspected and confirmed cases of infection by ZV (18). Some hypotheses suggest that the teratogenic mechanisms of $Z \mathrm{~V}$ are associated with the precipitation and deregulation of retinoic acid-dependent genes, extending the sequences in the genome that are closely involved with the development of the brain. This mechanism is known to be associated with other neurotropic viruses. For this reason, the spectrum of malformations generated by hypervitaminosis A presents with an embryopathy that appears similar to that of ZV $(19,20)$. Other researchers suggest a direct immune effect of the virus on neuronal cells as demonstrated in animal models where the high replication rate of ZV in progenitors of neuronal cells, which have a high concentration of viral receptors, is suggested to be the gateway to the entrance of the virus to the brain. Immunoreactivity with markers associated with cell death, such as caspases, leads to apoptosis of these cells and pyramidal corticospinal neurons, which ultimately generate the appearance of microcephaly as an external feature (21).

In Colombia, there were 657,126 reported cases of infection by ZV from April to June, 2016. Four percent of these cases were confirmed by PCR. 
The infection rate was two times higher in women than in men. Within this infected population, 11,944 pregnant women were reported, with $12 \%$ of these ZV cases confirmed by PCR; $90 \%$ of pregnant women who reported this infection gave birth to children with no apparent abnormalities. Fifty newborns were reported with possible microcephaly; 26 of these cases are still being investigated, while 20 have confirmed congenital defects that caused genetic and neural tube defects. Of these patients, four have evidence of congenital ZV infection that presents with microcephaly and without coinfections (22). It is important to understand the prevalence of microcephaly in Colombia in the years prior to the $\mathrm{ZV}$ epidemic in order to have a starting point to establish comparisons after its arrival to Colombia and assess its possible involvement in birth defects of the central nervous system, such as microcephaly.

In order to assess the prevalence of microcephaly in Colombia prior to the ZV epidemic, we conducted a systematic review of the literature. Articles included for consideration in the present study were those that addressed Colombian patients with microcephaly, as reported between 1982 and 2013. The primary outcome studied was the prevalence of microcephaly in Colombia during this period. The secondary outcome was the prevalence of birth defects of the central nervous system in Colombia during the period.

\section{Materials and methods}

The protocol for the systematic review was registered in the United Kingdom National Institute of Health and Research International Prospective Register of Systematic Reviews (PROSPERO) as number 48859.

The objective of the systematic review was to determine the prevalence of birth defects in Colombia from 1982 to 2013. Articles published in Spanish, English, and Portuguese were included. The inclusion criterium was cross-observational studies that determined the prevalence of birth defects in Colombia, including microcephaly as defined by the Latin American Collaborative Study of Congenital Malformations (ECLAMC). We excluded articles in which the diagnosis was done during the prenatal period, due to the absence of confirmation of microcephaly in these studies. The outcomes measured were the prevalence of microcephaly and the prevalence of central nervous system birth defects in Colombia between 1982 and 2013.
The search of the literature was performed in the different international, Latin American and national (Medline, Scopus, Science Direct, Lilacs, Dare, Bireme, and Cochrane) databases. The following Medical Subject Headings (MeSH) search terms were used: "birth defects," "microcephaly," "prevalence," and "Colombia." Additional Latin American and national data were obtained from the annual reports of the epidemiological surveillance of congenital malformations for articles published before April, 2015; the last search was performed in October, 2016. We searched for additional literature in the references reported in indexed articles. Moreover, some authors were contacted for additional sources of information. The eligible study designs included cross-sectional observational studies, cohort, casecontrol, ecological, and reports of the epidemiological surveillance of congenital malformations.

Articles and abstracts were examined independently by two reviewers in order to select those to be considered for complete text review based on the inclusion and exclusion criteria and, in case of disagreement, a third reviewer assessed the article and the decision was made by consensus. The data collected from each study were the number of cases of microcephaly, the period of time studied, the number of births and the number of defects of the central nervous system.

The limitations of the study include the fact that the definition of microcephaly varies in the literature. The definition used for data collection in this study, as well as in the majority of the reviewed articles, was head circumference less than three standard deviations of the mean for age and sex. To control this selection bias, we included studies performed in institutions using the ECLAMC criteria, since the institutions using this surveillance system feature a greater sensitivity, uniformity, and coverage of defects compared to those monitored by the surveillance system (Sistema de Vigilancia en Salud Pública, Sivigila) of the Instituto Nacional de Salud (23). In addition, another possible risk of bias was the failure to include a study in which microcephaly was evaluated. Therefore, we designed a system for searching those articles in which databases were searched and, subsequently, references in the articles found in order to minimize the loss of data.

\section{Data analysis}

We collected the data from eligible studies considering the study design, year of publication, authors, area, and period of the study. The following information was extracted from each article: The 
total number of malformations, the number of cases of microcephaly reported, the number of nervous system malformations, and the number of births in the period studied. These data were then combined and used to calculate the rates per 10,000 live births. In order to avoid repeating data, if the participants were included in more than one study, only the study with the greater sample size was included.

\section{Results}

Using the $\mathrm{MeSH}$ terms defined in the methodology, 32 articles were identified in the different databases, references and monitoring systems of national birth defects. Initially, the repeated articles were excluded, and after filtering the articles and applying the inclusion and exclusion criteria, 28 articles were eligible, of which 12 were included in the review since they accomplished the primary and secondary objectives of the research (figure 1).

The studies reviewed were published between 2003 and 2015 in Brazil and Colombia, all using data from Colombia. The period evaluated included 2,808,308 births, 21,363 malformations, 1,680 neurological malformations and 420 cases of microcephaly (table 1).

During the period evaluated, the surveillance system (Sivigila) of the Instituto Nacional de Salud was started started. In 2009, a pilot test was developed and an annual report for the 2010 period was published. During the period 20102013 , there were $2,655,796$ births, of which $0.35 \%$ had defects of some kind, including 1,248 reported malformations of the central and peripheral nervous system, which corresponded to an average of

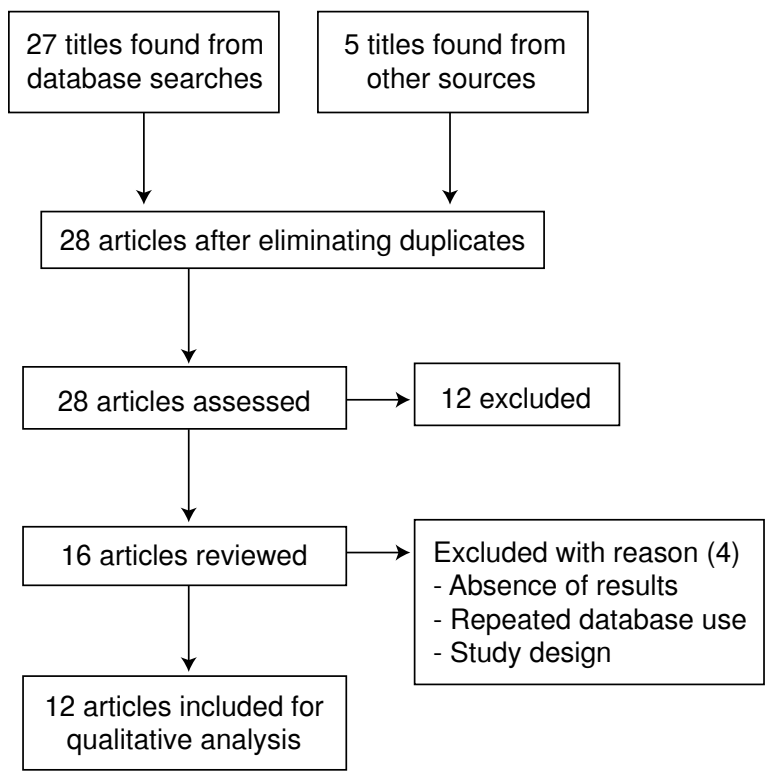

Figure 1. Flowchart of the study selection

$15.8 \%$ of all congenital malformations reported, with a prevalence of 4.85 per 10,000 . Of these, $3.38 \%$ corresponded to microcephaly, with an average prevalence of 1.17 cases per 10,000 births (table 2).

The prevalence of birth defects in the country varied between 8.7 and 68.9 per 10,000 live births from 2010 to 2013 according to Sivigila, an increase directly related with the coverage of this program nationwide. The highest reported rate of birth defects came from Bogotá, reaching 430.8 per 10,000 births. The lowest rate came from the department of Risaralda, reported as 89.8 per 10,000 births. The highest prevalence of microcephaly reported was from Bogotá, reaching

Table 1. Prevalence of microcephaly and central nervous system anomalies per 10,000 births in Colombia

\begin{tabular}{lcccc}
\hline Author, publication year, study period, study location & \multicolumn{2}{c}{ Microcephaly } & \multicolumn{2}{c}{$\begin{array}{c}\text { Central nervous system } \\
\text { anomalies }\end{array}$} \\
\cline { 2 - 5 } & $\begin{array}{c}\text { Number of } \\
\text { cases }\end{array}$ & $\begin{array}{c}\text { Number per } \\
\mathbf{1 0 , 0 0 0} \text { births }\end{array}$ & $\begin{array}{c}\text { Number of } \\
\text { cases }\end{array}$ & $\begin{array}{c}\text { Number per } \\
\mathbf{1 0 , 0 0 0} \text { births }\end{array}$ \\
\hline González Y, 2010, 2010, Colombia & 21 & 00.3 & 128 & 2.0 \\
González Y, 2011, 2011, Colombia & 70 & 10.1 & 346 & 5.2 \\
González Y, 2012, 2012, Colombia & 74 & 10.1 & 237 & 3.5 \\
Misnaza SP, 2013, 2013, Colombia & 142 & 20.2 & 573 & 8.7 \\
Pachajoa H, 2010,2004-2008, Cali, Colombia & 5 & 10.5 & 114 & 34.6 \\
Silva JR, 1998, 1987-1988, Barranquilla, Colombia & 1 & 20.7 & 10 & 26.6 \\
Ramírez J, 2015, 2011-2012, Cali, Colombia & 2 & 00.5 & 28 & 49.4 \\
López JS, 2015, 1982-2013, Colombia & 77 & 30.1 & $\mathrm{ND}$ & $\mathrm{ND}$ \\
García H, 2003, 1997-2000, Bogotá, Colombia & 2 & 30.5 & 31 & 54.5 \\
Porras GL, 2016, 2010-2013, Risaralda, Colombia & 13 & 30.1 & 73 & 17.2 \\
Zarante I, 2010, 2001-2008, Bogotá, Ubaté, Manizales, Colombia & 13 & 20.5 & 103 & 19.5 \\
Arteaga CE, 2003, 1991-1992, Bogotá, Colombia & 0 & 0.0 & 37 & 40.1 \\
\hline
\end{tabular}


Table 2. Description of articles consulted for the literature review

\begin{tabular}{|c|c|c|c|c|c|c|c|c|}
\hline $\begin{array}{l}\text { Author, } \\
\text { publication } \\
\text { year }\end{array}$ & Study objective & $\begin{array}{l}\text { Study } \\
\text { location }\end{array}$ & Study type & Study period & $\begin{array}{c}\text { Study } \\
\text { population }\end{array}$ & $\begin{array}{l}\text { Sample } \\
\text { size }\end{array}$ & $\begin{array}{l}\text { Outcome } \\
\text { variable } \\
\text { definition }\end{array}$ & Biases \\
\hline $\begin{array}{l}\text { González Y, } \\
2010\end{array}$ & $\begin{array}{l}\text { To report } \\
\text { congenital } \\
\text { anomalies in } 2010\end{array}$ & Colombia & $\begin{array}{l}\text { Routine } \\
\text { data from } \\
\text { epidemiologic } \\
\text { surveillance }\end{array}$ & 2010 & Births & 654,627 & $\begin{array}{l}\text { Head } \\
\text { circumference } \\
<3 \text { standard } \\
\text { deviations }\end{array}$ & $\begin{array}{l}\text { Limited to } \\
\text { coverage of } \\
\text { the national } \\
\text { surveillance } \\
\text { network }\end{array}$ \\
\hline $\begin{array}{l}\text { González Y, } \\
2011\end{array}$ & $\begin{array}{l}\text { To report } \\
\text { congenital } \\
\text { anomalies in } 2011\end{array}$ & Colombia & $\begin{array}{l}\text { Routine } \\
\text { data from } \\
\text { epidemiologic } \\
\text { surveillance }\end{array}$ & 2011 & Births & 665,499 & $\begin{array}{l}\text { Head } \\
\text { circumference } \\
<3 \text { standard } \\
\text { deviations }\end{array}$ & $\begin{array}{l}\text { Limited to } \\
\text { coverage of } \\
\text { the national } \\
\text { surveillance } \\
\text { network }\end{array}$ \\
\hline $\begin{array}{l}\text { González Y, } \\
2012\end{array}$ & $\begin{array}{l}\text { To report } \\
\text { congenital } \\
\text { anomalies in } 2012\end{array}$ & Colombia & $\begin{array}{l}\text { Routine } \\
\text { data from } \\
\text { epidemiologic } \\
\text { surveillance }\end{array}$ & 2012 & Births & 676,835 & $\begin{array}{l}\text { Head } \\
\text { circumference } \\
<3 \text { standard } \\
\text { deviations }\end{array}$ & $\begin{array}{l}\text { Limited to } \\
\text { coverage of } \\
\text { the national } \\
\text { surveillance } \\
\text { network }\end{array}$ \\
\hline $\begin{array}{l}\text { Misnaza SP, } \\
2013\end{array}$ & $\begin{array}{l}\text { To report } \\
\text { congenital } \\
\text { anomalies in } 2013\end{array}$ & Colombia & $\begin{array}{l}\text { Routine } \\
\text { data from } \\
\text { epidemiologic } \\
\text { surveillance }\end{array}$ & 2013 & Births & 658,835 & $\begin{array}{l}\text { Head } \\
\text { circumference } \\
<3 \text { standard } \\
\text { deviations }\end{array}$ & $\begin{array}{l}\text { Limited to } \\
\text { coverage of } \\
\text { the national } \\
\text { surveillance } \\
\text { network }\end{array}$ \\
\hline $\begin{array}{l}\text { Pachajoa H, } \\
2010\end{array}$ & $\begin{array}{l}\text { To evaluate birth } \\
\text { defects in a tertiary } \\
\text { care hospital }\end{array}$ & $\begin{array}{l}\text { Cali, } \\
\text { Colombia }\end{array}$ & $\begin{array}{l}\text { Observational- } \\
\text { Cross sectional }\end{array}$ & $2004-2008$ & Births & 32,995 & $\begin{array}{l}\text { Head } \\
\text { circumference } \\
<3 \text { standard } \\
\text { deviations }\end{array}$ & $\begin{array}{l}\text { Small sample } \\
\text { size }\end{array}$ \\
\hline $\begin{array}{l}\text { Silva JR, } \\
1998\end{array}$ & $\begin{array}{l}\text { To evaluate } \\
\text { congenital } \\
\text { malformations } \\
\text { and genetics } \\
\text { in a newborn } \\
\text { population }\end{array}$ & $\begin{array}{l}\text { Barranquilla, } \\
\text { Colombia }\end{array}$ & $\begin{array}{l}\text { Observational- } \\
\text { Cross sectional }\end{array}$ & 1987-1988 & Live births & 3,763 & $\begin{array}{l}\text { Head } \\
\text { circumference } \\
<3 \text { standard } \\
\text { deviations }\end{array}$ & $\begin{array}{l}\text { Small sample } \\
\text { size }\end{array}$ \\
\hline $\begin{array}{l}\text { Ramírez J, } \\
2015\end{array}$ & $\begin{array}{l}\text { To evaluate birth } \\
\text { defects in a tertiary } \\
\text { care hospital }\end{array}$ & $\begin{array}{l}\text { Cali, } \\
\text { Colombia }\end{array}$ & $\begin{array}{l}\text { Observational- } \\
\text { Cross sectional }\end{array}$ & $\begin{array}{c}\text { July, 2011-June, } \\
2012\end{array}$ & Births & 5,669 & $\begin{array}{l}\text { Head } \\
\text { circumference } \\
<3 \text { standard } \\
\text { deviations }\end{array}$ & $\begin{array}{l}\text { Small sample } \\
\text { size }\end{array}$ \\
\hline $\begin{array}{l}\text { López JS, } \\
2015\end{array}$ & $\begin{array}{l}\text { To evaluate } \\
\text { microcephaly in } \\
\text { ECLAMC and in } \\
\text { Brazil }\end{array}$ & Colombia & $\begin{array}{l}\text { Observational - } \\
\text { Case control }\end{array}$ & $1982-2013$ & Births & 249,746 & $\begin{array}{l}\text { Head } \\
\text { circumference } \\
<3 \text { standard } \\
\text { deviations }\end{array}$ & $\begin{array}{l}\text { Limited to } \\
\text { coverage of } \\
\text { the national } \\
\text { surveillance } \\
\text { network }\end{array}$ \\
\hline $\begin{array}{l}\text { García H, } \\
2003\end{array}$ & $\begin{array}{l}\text { To evaluate } \\
\text { the prevalence } \\
\text { of congenital } \\
\text { anomalies at the } \\
\text { Instituto Materno- } \\
\text { Infantil de Bogotá }\end{array}$ & $\begin{array}{l}\text { Bogotá, } \\
\text { Colombia }\end{array}$ & $\begin{array}{l}\text { Observational- } \\
\text { Cross sectional }\end{array}$ & $\begin{array}{l}\text { October, } \\
\text { 1997-April, } \\
\text { 1998, July, } \\
2000- \\
\text { November, } \\
2000\end{array}$ & Births & 5,686 & $\begin{array}{l}\text { Head } \\
\text { circumference } \\
<3 \text { standard } \\
\text { deviations }\end{array}$ & $\begin{array}{l}\text { Study } \\
\text { performed } \\
\text { during a } \\
\text { discontinuous } \\
\text { time period }\end{array}$ \\
\hline $\begin{array}{l}\text { Porras GL, } \\
2016\end{array}$ & $\begin{array}{l}\text { To determine the } \\
\text { prevalence of } \\
\text { congenital defects }\end{array}$ & $\begin{array}{l}\text { Risaralda, } \\
\text { Colombia }\end{array}$ & $\begin{array}{l}\text { Observational- } \\
\text { Cross sectional }\end{array}$ & $\begin{array}{l}\text { July, 2010- } \\
\text { December, } \\
2013\end{array}$ & Births & 42,431 & $\begin{array}{l}\text { Head } \\
\text { circumference } \\
<3 \text { standard } \\
\text { deviations }\end{array}$ & $\begin{array}{l}\text { Small sample } \\
\text { size }\end{array}$ \\
\hline $\begin{array}{l}\text { Zarante I, } \\
2010\end{array}$ & $\begin{array}{l}\text { To determine } \\
\text { the prevalence } \\
\text { of congenital } \\
\text { malformations } \\
\text { and assess the } \\
\text { prognosis of } \\
\text { newborns }\end{array}$ & $\begin{array}{l}\text { Bogotá, } \\
\text { Ubaté, and } \\
\text { Manizales, } \\
\text { Colombia }\end{array}$ & $\begin{array}{l}\text { Observational- } \\
\text { Cross sectional }\end{array}$ & $\begin{array}{c}\text { April, } \\
\text { 2011-January, } \\
2008\end{array}$ & Births & 52,744 & $\begin{array}{l}\text { Head } \\
\text { circumference } \\
<3 \text { standard } \\
\text { deviations }\end{array}$ & $\begin{array}{l}\text { Small sample } \\
\text { size }\end{array}$ \\
\hline $\begin{array}{l}\text { Arteaga CE, } \\
2003\end{array}$ & $\begin{array}{l}\text { To assess the } \\
\text { prevalence and } \\
\text { factors associated } \\
\text { with congenital } \\
\text { anomalies at the } \\
\text { Instituto Materno- } \\
\text { Infantil de Bogotá }\end{array}$ & $\begin{array}{l}\text { Bogotá, } \\
\text { Colombia }\end{array}$ & $\begin{array}{l}\text { Observational - } \\
\text { Cross sectional }\end{array}$ & 1991-1992 & Births & 9,224 & $\begin{array}{l}\text { Head } \\
\text { circumference } \\
<3 \text { standard } \\
\text { deviations }\end{array}$ & $\begin{array}{l}\text { Small sample } \\
\text { size }\end{array}$ \\
\hline
\end{tabular}


3.5 per 10,000 births in 2003. In the period of study, the rate of central nervous system defects in Colombia ranged from 2 to 8.7 , with microcephaly ranging from 0.3 to 3.1 per 10,000 births. On average, the prevalence of these defects and microcephaly was $23.5(95 \% \mathrm{Cl} 23.1-24)$ and 1.8 (95\% Cl 1.7-1.8) per 10,000 births, respectively. The study that reported the highest prevalence for microcephaly in the country was by ECLAMC during the period 1982-2013. In this study, 24,976 births were reported, of which 77 were registered with microcephaly, leading to a prevalence of 3.08 per 10,000 births for the follow-up period (table 2).

\section{Discussion}

Congenital defects are a worldwide public health problem. It is estimated that 7.9 million children are born with congenital defects every year, with 3.3 million children under 5 years of age dying due to these defects and 3.2 million surviving with disabilities (24). As a cause of infant death in Colombia in recent decades, congenital anomalies ranked seventh in 1970, fourth in 1980 and third in 1994 (25). From 2000 to 2004, a total of 14,036 deaths from congenital anomalies was reported in Colombia, with a mortality rate of 8.43 per 10,000 births (26). From 2005 to 2011, congenital defects were reported as the second leading cause of death in children under one year of age, contributing to $20.8 \%$ of all deaths, according to the Departamento Administrativo Nacional de Estadísticas (DANE) (27). According to the analysis of the health situation in Colombia, congenital defects are the second leading cause of infant mortality. The available evidence suggests that the prevalence and the potential burden of congenital disorders in public health are high in developing countries and, in some circumstances, they are greater than in developed countries. Birth defects in Colombia are responsible for $23 \%$ of the total mortality in children under 5 years of age (28), a clinically significant issue that has been declared a public health problem (29).

After the ZV outbreak in the Americas, birth defects such as microcephaly have gained particular clinical relevance. Before the epidemic, the definition of microcephaly was heterogeneous, controversial, and varied between institutions (30). Some authors classify microcephaly as a head circumference less than two standard deviations from median values (31). Other authors suggest that this measure should be necessarily adjusted to prematurity and to the length of patients' head circumference
$(9,32)$. Assuming that the cephalic perimeter has a normal distribution across the population, 2.3\% of all children would be defined as having microcephaly. Despite this, literature estimates that less than $0.54 \%$ to $0.56 \%$ of children are classified with a head circumference less than two standard deviations, which suggests a non-normal distribution of this measure (9). The true number of cases of microcephaly in Brazil, where the ZV epidemic was first associated with the condition, was unknown since this event was overestimated, no active search was done, and its diagnosis was based on non-standardized criteria before the associations between Zika and congenital defects (30).

We conducted a systematic review of the literature regarding the frequency of microcephaly in Colombia. The objective was to determine the prevalence of microcephaly in the country before the ZV epidemic and to establish whether there was a change in the prevalence of microcephaly per 10,000 births. Such information would allow us to determine if the increase of microcephaly cases was significant and develop a better approach to the Zika virus epidemic in Colombia and its association with congenital defects.

During the study period, microcephaly was equivalent to $3.38 \%$ of congenital defects and its prevalence rate fluctuated between 0.3 to 3.1 per 10,000 live births, with an average rate of 1,56 per 10,000 live births from 1982 to 2013. Compared with the rate of microcephaly in the rest of Latin American countries, Colombia's rate falls within the average since ECLAMC rate per 10, 000 live births was $4.53(95 \% \mathrm{Cl} 4.05-5.02)$ in Brazil and 4.30 (95\% Cl 2.57-3.22) in Chile, compared with 3.08 per 10,000 live births $(95 \% \mathrm{Cl} 2.04-3.84)$, which does not surpass the global rate of microcephaly according to ECLAMC, which was $3.30(95 \% \mathrm{Cl}$ 3.09-3.50) per 10,000 live births between 1982 and 2013. According to ECLAMC, from 1982 to 2013, Brazil and Chile had the highest prevalence of microcephaly in Latin America (33).

In the study period, few Colombian departments and cities had surveillance systems for reporting birth defects such as microcephaly. Among the studies found in literature, microcephaly, defined as a head circumference less than three standard deviations when adjusted for age and sex, we found those from Cali, Barranquilla, Bogotá, Risaralda, Manizales, and Ubaté. Besides these studies, microcephaly had also been reported in articles assessing birth defects across Colombia. 
This relatively small amount of reporting on microcephaly could be explained by the low frequency of the event, which leads to its exclusion in the final statistics. Nevertheless, the number of reports of congenital malformations has increased in recent years, as noted in the annual report of Sivigila, which may be explained by an increase in reporting or an increase in the rate of microcephaly. We were unable to make this distinction in the present study, which represents a limitation.

Compared to the prevalence of microcephaly reported by ECLAMC from 1982 to 2013, the prevalence reported by Sivigila from 2010 to 2013 was lower, with an average prevalence of 1.5 births with microcephaly per 10,000 births. The studies reported and included in this review only classified the defects and described the frequency of microcephaly, but did not discriminate according to etiology. In the present review, we could not find any observational cohort studies or case-control studies evaluating the risks and other measures of association of microcephaly in Colombia. However, the different cross-sectional studies reported in the country confirmed the existence of microcephaly before the emergence of autochthonous ZV in the country.

One limitation of this study was the variability of the diagnostic criteria of microcephaly. We used the more rigorous criteria, that of less than three standard deviations of head circumference, adjusted for age and sex. Consequently, studies using other criteria for microcephaly were not included. Additionally, it is possible that not all relevant studies were found and included in the review, although we adopted measures to reduce the likelihood of this limitation.

Finally, the prevalence of microcephaly in Colombia from 1982 to 2013 , before the introduction of ZV, ranged from 0.3 to 3.1 per 10,000 births, with an average of $1.8(95 \% \mathrm{Cl} 1.7-1.8)$ per 10,000 births. These findings are important to determine if the prevalence after the introduction of the Zika virus has meant significant changes.

\section{Funding}

There was no funding source for this study.

\section{Acknowledgements}

To Universidad Icesi, Fundación Valle del Lili, and the Centro Internacional de Entrenamiento e Investigaciones Médicas (CIDEIM) for their continued collaboration on this work.

\section{References}

1. Ministerio de Salud, Instituto Nacional de Salud. Protocolo de Vigilancia en Salud Pública: defectos congénitos. Bogotá: Instituto Nacional de Salud; 2014.

2. Ashwal S, Michelson D, Plawner L, Dobyns WB, Quality Standards Subcommittee of the American Academy of Neurology and the Practice Committee of the Child Neurology Society. Practice parameter: Evaluation of the child with microcephaly (an evidence-based review): Report of the Quality Standards Subcommittee of the American Academy of Neurology and the Practice Committee of the Child Neurology Society. Neurology. 2009;73:887-97. https://doi.org/10.1212/WNL.0b013e3181b783f7

3. World Health Organization. Screening, assessment and management of neonates and infants with complications associated with Zika virus exposure in utero. Geneva: World Health Organization; 2016.

4. Jaworski M, Hersh JH, Donat J, Shearer LT, Weisskopf B. Computed tomography of the head in the evaluation of microcephaly. Pediatrics. 1986;78:1064-9.

5. Steinlin M, Zürrer M, Martin E, Boesch C, Largo RH, Boltshauser E. Contribution of magnetic resonance imaging in the evaluation of microcephaly. Neuropediatrics. 1991;22:184-9. https://doi.org/10.1055/s-2008-1071438

6. Sugimoto T, Yasuhara A, Nishida N, Murakami K, Woo M, Kobayashi Y. MRI of the head in the evaluation of microcephaly. Neuropediatrics. 1993;24:4-7. https://doi. org/10.1055/s-2008-1071504

7. Opitz JM, Holt MC. Microcephaly: General considerations and aids to nosology. J Craniofac Genet Dev Biol. 1990;10:175-204

8. Stoll C. Problems in the diagnosis of fragile $X$ syndrome in young children are still present. Am J Med Genet. 2001; 100:110-5. https://doi.org/10.1002/1096-8628(20010422)100: 2<110::AID-AJMG1242>3.0.CO;2-I

9. Dolk $\mathbf{H}$. The predictive value of microcephaly during the first year of life for mental retardation at seven years. Dev Med Child Neurol. 1991;33:974-83. https://doi.org/10.1111/ j.1469-8749.1991.tb14813.x

10. Rasmussen SA, Jamieson DJ, Honein MA, Petersen LR. Zika virus and birth defects--reviewing the evidence for causality. N Engl J Med. 2016;374:1981-7. https://doi. org/10.1056/NEJMsr1604338

11. Mysorekar IU, Diamond MS. Modeling Zika virus infection in pregnancy. N Engl J Med. 2016;375:481-4. https://doi. org/10.1016/j.cell.2016.05.008

12. Mlakar J, Korva M, Tul N, Popović M, Poljšak-Prijatelj M, Mraz J, et al. Zika virus associated with microcephaly. N Engl J Med. 2016;374:951-8. https://doi.org/10.1056/ NEJMoa1600651

13. Schuler-Faccini L, Ribeiro EM, Feitosa IM, Horovitz DD, Cavalcanti DP, Pessoa A, et al. Possible association between zika virus infection and microcephaly - Brazil, 2015. MMWR Morb Mortal Wkly Rep. 2016;65:59-62. https://doi. org/10.15585/mmwr.mm6503e2

14. World Health Organization. Disease outbreak news. Microcephaly-Brazil. 2016;91:237-48. Accessed: June 22, 2018. Available at: http://www.who.int/wer/2016/wer9118/en/ 
15. World Health Organization. Microcephaly - Brazil. Weekly Epidemiological Record. Accessed: June 22, 2018. Available at: http://www.who.int/csr/don/8-january-2016-brazilmicrocephaly/en/

16. Gulland A. Zika virus is a global public health emergency, declares WHO. BMJ. 2016;352:i657. https://doi.org/10.1136/ bmj. 657

17. Fauci AS, Morens DM. Zika virus in the Americas - yet another arbovirus threat. N Engl J Med. 2016;374:601-4. https://doi.org/10.1056/NEJMp1600297

18. Rubin EJ, Greene MF, Baden LR. Zika virus and microcephaly. N Engl J Med. 2016;374:984-5. https://doi.org/10. 1056/NEJMe1601862

19. Kumar A, Singh HN, Pareek V, Raza K, Dantham S, Kumar $\mathbf{P}$, et al. A possible mechanism of Zika virus associated microcephaly: Imperative Role of Retinoic Acid Response Element (RARE) Consensus Sequence Repeats in the Viral Genome. Front Hum Neurosci. 2016;10:403. https://doi.org/10.3389/fnhum.2016.00403

20. Mawson AR. Pathogenesis of Zika virus-associated embryopathy. Biores Open Access. 2016;5:171-6. https:// doi.org/10.1089/biores.2016.0004

21. Huang W-C, Abraham R, Shim B-S, Choe H, Page DT. Zika virus infection during the period of maximal brain growth causes microcephaly and corticospinal neuron apoptosis in wild type mice. Sci Rep. 2016;6:34793. https:// doi.org/10.1038/srep34793

22. Pacheco O, Beltrán M, Nelson CA, Valencia D, Tolosa N, Farr SL, et al. Zika virus disease in Colombia - preliminary report. N Engl J Med. 2016. p. 1-10. https://doi.org/10.1056/ NEJMoa1604037

23. Porras GL, León OM, Molano J, Quiceno SL, Pachajoa H, Montoya JJ. Prevalencia de defectos congénitos en Risaralda, 2010-2013. Biomédica. 2016;36:556-63. https:// doi.org/10.7705/biomedica.v36i4.2771
24. Carmona RH. The global challenges of birth defects and disabilities. Lancet. 2005;366:1142-4. https://doi.org/10. 1016/S0140-6736(05)67459-4

25. Medina MR. Geografía de la mortalidad infantil en Colombia, 1985-1994. Bogotá: Departamento Administrativo Nacional de Estadística (DANE); 1999.

26. González Y. Informe final del evento anomalías congénitas hasta el periodo epidemiológico 13 del año 2012. Bogotá: Instituto Nacional de Salud; 2012.

27. Observatorio Nacional de Salud. Tercer informe ONS: Mortalidad evitable en Colombia para 1998-2011. Bogotá: Instituto Nacional de Salud; 2014.

28. Organización Mundial de la Salud. Estadísticas sanitarias mundiales, 2014. Geneva: Organización Mundial de la Salud; 2014. p. 13-22.

29. García H, Salguero GA, Moreno J, Arteaga C, Giraldo A. Frecuencia de anomalías congénitas en el Instituto Materno-Infantil, Bogotá. Biomédica. 2003;23:161-72. https://doi.org/10.7705/biomedica.v23i2.1208

30. Victora CG, Schuler-Faccini L, Matijasevich A, Ribeiro E, Pessoa A, Barros FC. Microcephaly in Brazil: How to interpret reported numbers? Lancet. 2016;387:621-4. https://doi.org/10.1016/S0140-6736(16)00273-7

31. Boom JA. Microcephaly in infants and children: Etiology and evaluation. Accessed on: June 22, 2018. Available at: https://www.uptodate.com/contents/microcephaly-in-infantsand-children-etiology-and-evaluation

32. Roche AF, Mukherjee D, Guo SM, Moore WM. Head circumference reference data: Birth to 18 years. Pediatrics. 1987;79:706-12.

33. Estudio Colaborativo Latino Americano de Malformaciones Congénitas. Microcefalia no ECLAMC e no Brasil. Buenos Aires: Estudio Colaborativo LatinoAmericano de Malformaciones Congénitas; 2015. 